\title{
NUMERICAL OPTIMIZATION OF THE METHOD OF COOLING OF A MASSIVE CASTING OF DUCTILE CAST-IRON
}

\author{
NUMERIČNA OPTIMIZACIJA POSTOPKA HLAJENJA PRI \\ MASIVNEM ULIVANJU DUKTILNE ŽELEZOVE LITINE
}

\author{
Frantisek Kavicka $^{1}$, Bohumil Sekanina ${ }^{1}$, Josef Stetina ${ }^{1}$, Karel Stransky ${ }^{1}$, \\ Vasilij Gontarev ${ }^{2}$, Jana Dobrovska ${ }^{3}$ \\ ${ }^{1}$ Brno University of Technology, Technicka 2, 61669 Brno, Czech Republic \\ ${ }^{2}$ University of Ljubljana, Aškerčeva 12, 1000 Ljubljana, Slovenia \\ ${ }^{3}$ Technical University of Ostrava, Tr.17. listopadu, Ostrava, Czech Republic \\ kavicka@fme.vutbr.cz \\ Prejem rokopisa - received: 2009-01-19; sprejem za objavo - accepted for publication: 2009-01-27
}

\begin{abstract}
An original application of ANSYS simulating the forming of the temperature field of a massive casting from ductile cast-iron during the application various methods of its cooling using steel chills. The numerical model managed to optimize more than one method of cooling but, in addition to that, provided serious results for the successive model of structural and chemical heterogeneity, and so it also contributes to influencing the as solidified microstructure. The file containing the acquired results from both models, as well as from their organic unification, brings new and, simultaneously, remarkable findings of causal relationships between the structural and chemical heterogeneity and the local solidification time in any point of the casting. Therefore the determined relations enable the prediction of the local density of the spheroids of graphite in dependence on the local solidification time.

The calculated temperature field of a two-ton $(500 \times 500 \times 1000) \mathrm{mm}$ casting of ductile cast-iron with various methods of cooling has successfully been compared with temperatures obtained experimentally. This has created a tool for the optimization of the microstructure with an even distribution of the spheroids of graphite in such a way so as to minimize the occurrence of degenerated shapes of graphite, which happens to be one of the conditions for achieving good mechanical properties of castings of ductile cast-iron.

Key-words: ductile cast-iron, massive casting, cooling, temperature field, numerical model
\end{abstract}

Uporaba originalnega programa ANSYS omogoča simulacijo tvorbe temperaturnega polja v masivnem litoželeznem ulitku pri različnih metodah hlajenja $\mathrm{z}$ jeklenimi hladilnimi telesi. Z numeričnim modelom se lahko optimira več metod hlajenja, dodatno pa je mogoč izračun pomembnih rezultatov za modeliranje strukturne in kemijske heterogenosti, kar tudi prispeva $\mathrm{k}$ vplivu na lito mikrostrukturo. Dobljeni rezultati obeh modelov omogočajo pomembne ugotovitve o odnosih med strukturno in kemijsko heterogenostjo ter lokalnim časom strjevanja $\mathrm{v}$ poljubni točki ulitka in napoved lokalne gostote krogličastega grafita $\mathrm{v}$ odvisnosti od lokalnega časa strjevanja.

Izračunano temperaturno polje dvotonskega ulitka duktilne železove litine z izmerami $(500 \times 500 \times 1000)$ mm je bilo v skladu z eksperimentalnimi rezultati pri različnih metodah hlajenja. Na podlagi teh ugotovitev je bilo izdelano orodje za optimizacijo mikrostrukture z enakomerno porazdelitvijo krogličastega grafita, s čimer se zmanjša pojav degeneriranih oblik grafita in se ustvarijo pogoji za dosego dobrih mehanskih lastnosti ulitkov duktilne železove litine.

Ključne besede: temperaturno polje, strjevanje, ohlajanje, numerična optimizacija, strukturna in kemijska heterogenost

\section{INTRODUCTION}

Solidification and cooling of a classically (i.e. gravitationally) cast casting and the simultaneous heating of the mould is, from the viewpoint of thermokinetics, a case of three-dimensional (3D) transient heat and mass transfer in a system consisting of the casting, mould and ambient. If the mass transfer is neglected and - from the three basic types of heat transfer - conduction is considered as the decisive, then the problem can be reduced to the solving of the Fourier equation. Here, the used 3D model of the temperature field of the system is based on the numerical finite-element method. The simulation of the release of the latent heats of phase or microstructural changes is carried out by introducing the thermodynamic enthalpy function. It enables the evaluation of the temperature field within the actual casting, chills and mould at any point in time within the process of solidification and cooling using contour lines (i.e. so-called iso-lines and iso-zones) or temperature-time curves for any nodal point of the system. It is possible to use all sophisticated sub-programs of ANSYS, such as automatic mesh generation, pre-processing and post-processing.

Having one's own numerical model available makes it possible to integrate one's own idea of the optimal course of solidification and cooling of the object under investigation in accordance with the latest findings and experiences of a specific operation. This is the main part of the role of the technological worker, irreplaceable by any computer technology whatsoever. Computer technology, despite its perfection, is only a tool enabling real-time prediction of his/her technical thinking and decisions. 
The quality of a massive casting of cast iron with spheroidal graphite is determined by all the parameters and factors that affect the metallographic process and also others. This means the factors from sorting, melting in, modification and inoculation, casting, solidification and cooling inside the mold and heat treatment.

The heterogeneous pouring field is formed in such a way that the process of casting always takes a longer period of time. The different parts of the melt have trajectories of differing lengths within the mold and lose different amounts of heat. Therefore, the pouring times must be short enough in order to reduce the heterogeneity of the temperature field as much as possible. Otherwise there is the danger, especially with massive castings - even with modularly evened out pouring — of a temporally different course of eutectic solidification with a varying density of spheroids of graphite in its individual parts. The results are unequal mechanical properties along the section, especially a ductility decrease.

The cooling rate of during solidification and cooling in the mold is a significant quantity influencing the forming of the microstructure. It works not only on the morphology of the graphite but also on the segregation of elements in austenite and its transformation. The increasing rate of cooling increases the number of spheroids and improves the nodular character of the spheroids of graphite. It shortens the distances between the eutectic grains (i.e. cells) reducing the segregation on their boundaries. Simultaneously, it decreases the heterogeneity of the pouring temperature field, it minimizes the heat convection of liquid ductile cast-iron, attempting to prevent the forming of chunky graphite inside large cross-sections. The rate of cooling is not an isolated process. Furthermore, the oxygen balance and eutectic temperature influence the density of the spheroids with mutual interaction.

This paper deals with the simulation of solidification and cooling of a massive casting, with various ways of accelerated cooling using steel chills in order to reduce the heterogeneity of the pouring temperature field and to increase the rate of cooling of the casting. The results of the simulation are compared with experimentally measured temperatures. It seems that numerically controlled cooling enables the optimization of the technology of pouring of massive ductile cast-iron castings with spheroidal graphite.

\section{NUMERICAL MODEL OF THE TEMPERATURE FIELD}

The numerical model of the temperature field must observe two main goals: directed solidification as the basic condition for the healthiness of a casting and the optimization of the technology of pouring while optimizing the utility properties of the product. The main goal achieved - in terms of the economics-is the saving of liquid metal, molding materials, the saving of energy and the already mentioned optimization of pouring and also the improvement of the properties of the cast product.

The solidification and cooling of a classically cast (i.e. gravitationally poured) casting and the simultaneous heating of the mold is, from the viewpoint of thermokinetcs, a case of 3D transient heat and mass transfer.

In systems comprising the casting, the mold and ambient, all three kinds of heat transfer take place. Since these problems cannot be solved analytically-even with the second-order partial differential Fourier equation (1) (where mass transfer is neglected and conduction is considered as the most important of the three kinds of heat transfer) - it is necessary to engage numerical methods. Equation (1) describes the transient temperature field in a mold. Its properties $k, c$ and $\rho$ are considered to be constant.

$$
\frac{\partial T}{\partial \tau}=\frac{k}{\rho \cdot c}\left(\frac{\partial^{2} T}{\partial x^{2}}+\frac{\partial^{2} T}{\partial y^{2}}+\frac{\partial^{2} T}{\partial z^{2}}\right)
$$

The Fourier equation for a casting must be adapted so as to describe the temperature field of a casting in all its three phases: in the melt, in the mushy zone and in the solid phase. Here it is necessary to introduce the specific volume enthalpy $h_{\mathrm{v}}=c \rho T$, which is dependent on temperature. The thermodynamic enthalpy function includes the latent heat of phase or structural changes. The equation then takes on the form

$$
\frac{\partial h_{\mathrm{v}}}{\partial \tau}=\frac{\partial}{\partial x}\left(k \frac{\partial T}{\partial x}\right)+\frac{\partial}{\partial y}\left(k \frac{\partial T}{\partial y}\right)+\frac{\partial}{\partial z}\left(k \frac{\partial T}{\partial z}\right)
$$

The specific heat capacity $c$, density $\rho$ and heat conductivity $k$ are also functions of temperature. The temperature of the general nodal point of the casting is obtained from the enthalpy-temperature dependence, which must be known for the relevant ductile cast-iron (Figure 1). The software pack ANSYS had been chosen

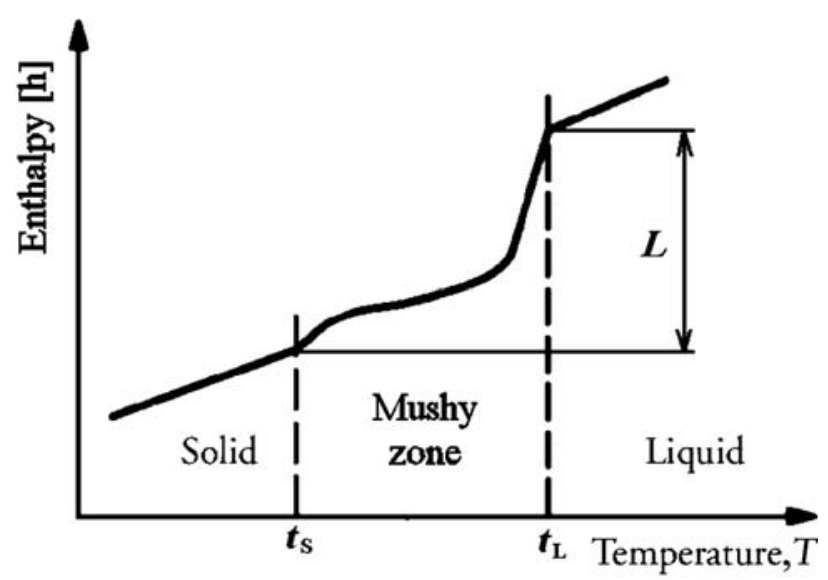

Figure 1: Enthalpy as a function of temperature Slika 1: Odvisnost entalpije od temperature 
for this investigation because it enables the application of the most convenient method of numerical simulation of the release of latent heat of phase and structural changes using the thermodynamic enthalpy function.

The program also considers the non-linearity of the task, i.e.:

- The dependence of the thermophysical properties (of all materials entering the system) on the temperature, and

- The dependence of the heat-transfer coefficients (on all boundaries of the system) on the temperature of the surface of the casting and mold.

ANSYS has an integrated mesh generator (i.e. preprocessing) as well as graphical output (i.e. post-processing) of the results and the user can change the pouring parameters, the dimensions of the casting-mold system and the dimensions of the elementary mesh volume before the actual calculation. The density of the mesh makes it possible to approximate the linear distribution of temperatures between individual points of the 3D mesh, and even within time intervals.

The accuracy of the numerical solution depends not only on the spatial and temporal discretization, but also on the precision with which the thermophysical properties of all materials entering the system are determined, and also on how precisely the boundary conditions are derived.

\section{THE PROBLEM}

The application of the 3D numerical model on a transient temperature field requires systematic experimentation, including the relevant measurement of the operational parameters directly in the foundry. The results of the measurement, which is focused on measuring temperatures, serve not only to verify the exactness of the model, but also to maintain continuity of the procedure: real process (risering, melting, pouring, solidification, etc.) $\rightarrow$ input data $\rightarrow$ numerical analysis $\rightarrow$ optimization $\rightarrow$ correction of real process (risering, melting, pouring, solidification, etc.).

A real $(500 \times 1000 \times 500)$ mm ductile cast-iron block had been used for the numerical calculation and the experiment (Figures 2 and 3 ).

Temperature measurement (using thermocouples) and its successive confrontation with the calculation proved that it is possible to apply the numerical model on basic calculations of solidification and cooling of the casting. It is also possible to determine the temperature gradients, the rate of solidification and the local solidification times (i.e. the time for which the given point of the casting finds itself between the liquidus and solidus temperatures). The local solidification time $\theta$ (according to the analogy from steels) significantly influences the forming of the as solidified structure of the given material.
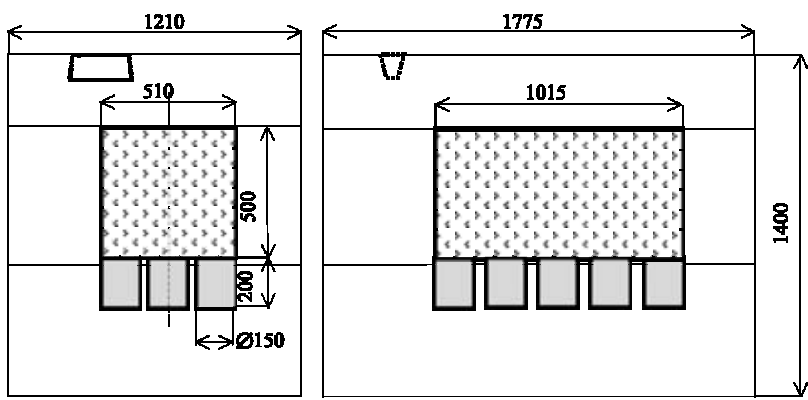

Figure 2: A picture showing the forming of casting no. 1 with chills on one side

Slika 2: Formiranje ulitka št.1 s hlajenjem na eni strani

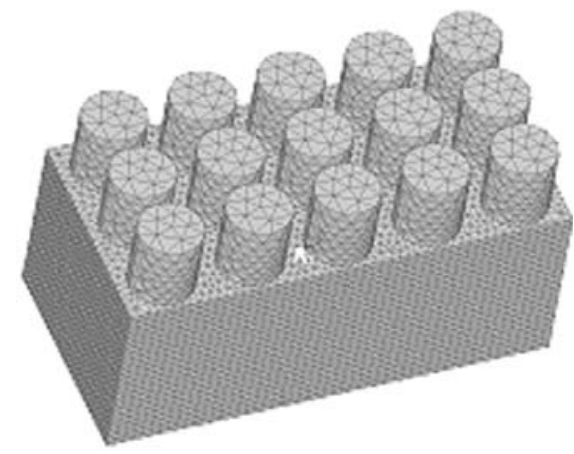

Figure 4: The mesh inside the chills and casting no. 1 Slika 4: Žična mrežica znotraj hladil in ulitka št. 1

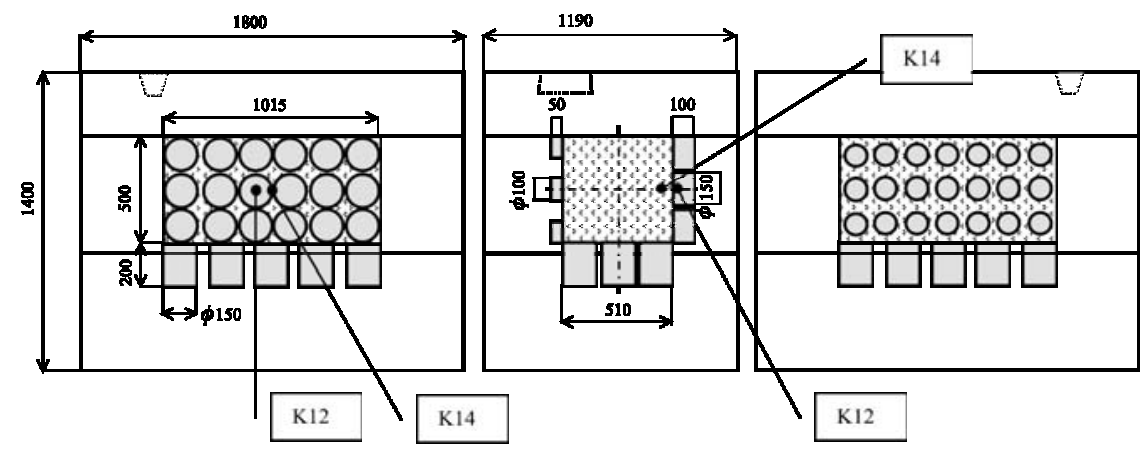

Figure 3: A picture showing the forming of casting no. 2 with chills on three sides Slika 3: Formanje ulitka št. $2 \mathrm{~s}$ hlajenjem na treh straneh 


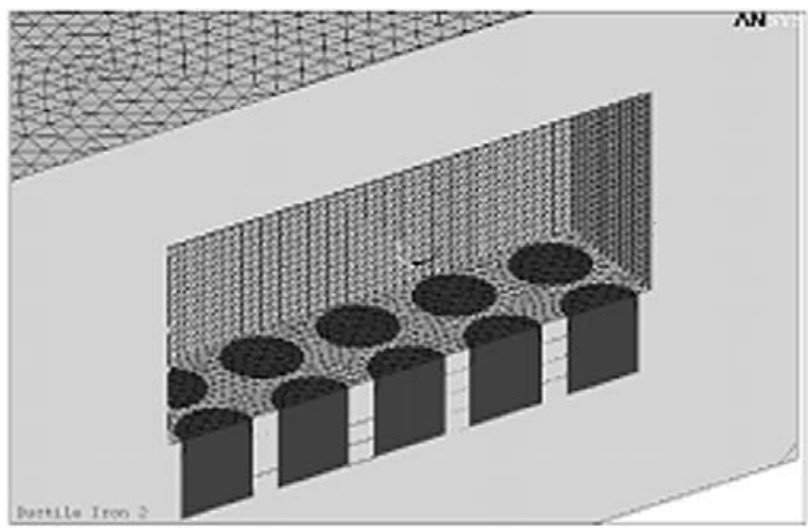

Figure 5: A detailed view of the mesh inside the chills and mold for casting no. 1

Slika 5: Podroben pogled na žične mrežice znotraj hladil in forme za ulitek št. 1

The investigated experimental castings weigh approximately $2 \mathrm{t}$. They were cast into sand molds with various arrangements of steel chills of cylindrical shape. The dimensions of the castings, the mold, the chills and their arrangements are illustrated in Figures 2 and 3.

Figures 4 and 5 show an example of the mesh generated by ANSYS.

\section{TEMPERATURE MEASUREMENT}

The temperature was measured using K- and B-type thermocouples and special thermocouple probes of type PtRh6 - PtRh30. The recording was carried out by the data-acquisition device GRANT 1250. The measuring ends of the thermocouples were placed in holes of $2 \mathrm{~mm}$ in diameter. The initial temperature of the mold and chills was approximately $20{ }^{\circ} \mathrm{C}$, the mold was filled through the top inlet gate with a melt at $1300{ }^{\circ} \mathrm{C}$. The courses of the temperatures were measured on casting no. 1 for $19 \mathrm{~h} 11 \mathrm{~min}$ and $19 \mathrm{~h} 20 \mathrm{~min}$ on casting no. 2 after casting.

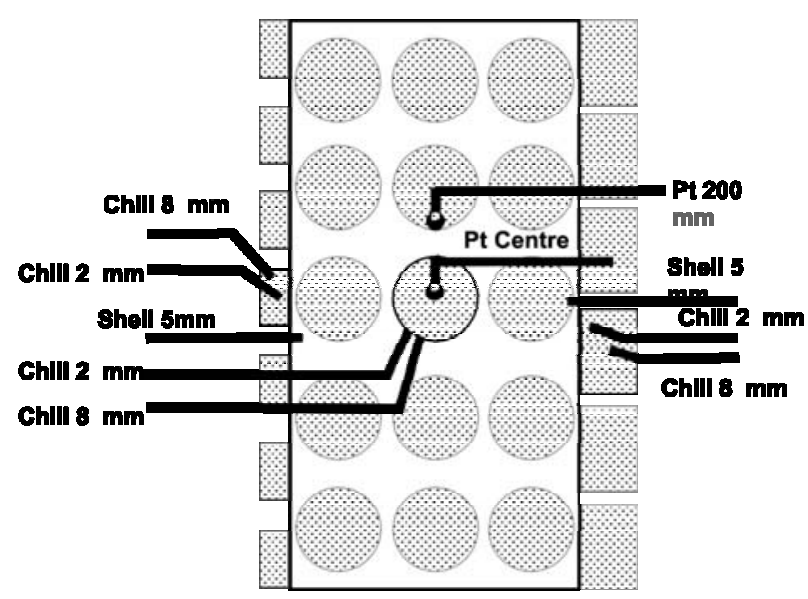

Figure 6: The measured positions for casting no. 2 Slika 6: Lega hladil pri ulitku št. 2

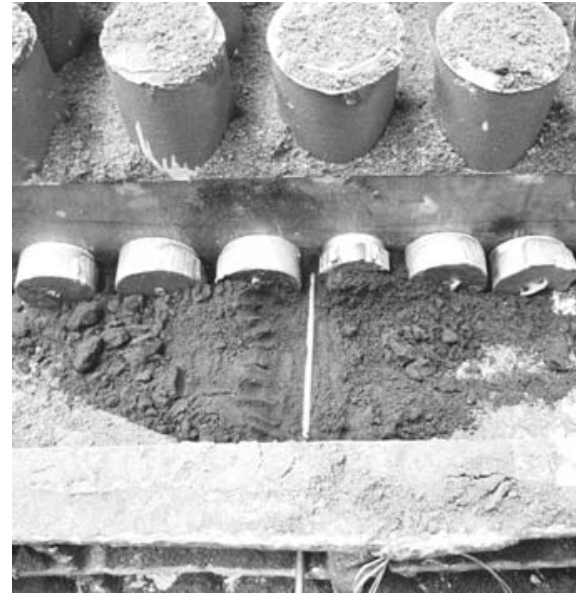

Figure 7: The installations of the thermocouples while molding casting no. 2

Slika 7: Namestitev termočlenov med formanjem ulitka št. 2

The positions of the probes and a view of the actual installation in mold no. 2 are illustrated in Figures 6 and 7.

\section{CALCULATION AND EXPERIMENTAL RESULTS}

The points in casting no. 2 and the chill were selected for comparison (Figures 3 and 6 respectively). The computation and experimental curves are in Figures 8 and 9.

It is obvious, that in the compared points of the mold and chills, the results from the numerical model correspond to those measured, which applies to most other places where both the mold and chills were measured. In the centers of the casting it was not possible to carry out the comparison due to a failure in the thermocouple probes.

The iso-zones, calculated in castings 1 and 2 and in the chills in various parts after casting, are illustrated in

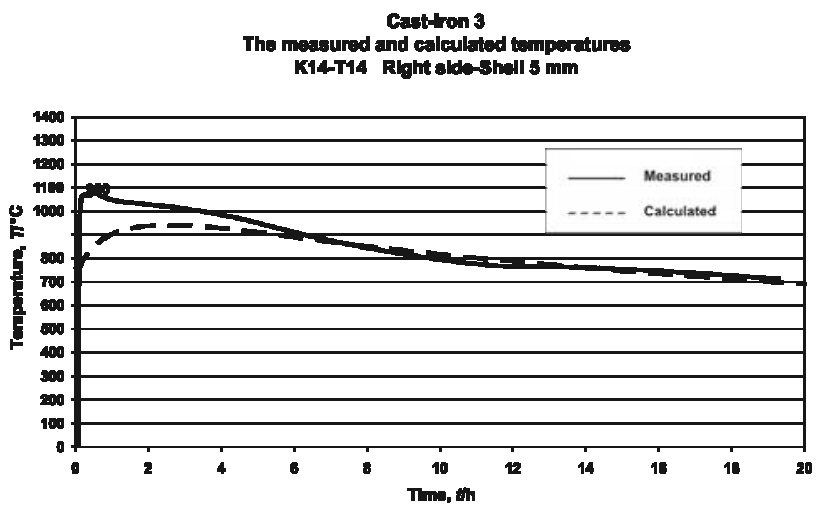

Figure 8: The measured and calculated temperature history in casting no. $2,5 \mathrm{~mm}$ beneath its surface

Slika 8: Merjene in izračunane temperature $5 \mathrm{~mm}$ pod površino ulitka št. 2 


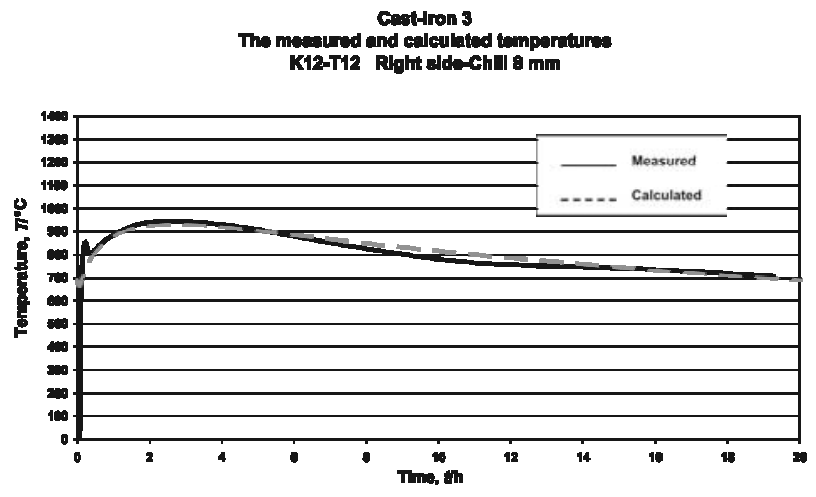

Figure 9: The measured and calculated temperature history in the chill for casting no. 2

Slika 9: Merjene in izračunane temperature v hladilih ulitka št. 2

Figures 10 and 11. The comparison of the iso-zones, including the mushy zone in castings 1 and 2 shows that this time is, relatively, not very much influenced by the increase in the number of chills or by the increase in the number of walls on which the chills are mounted.

The total solidification time of casting no. 1 is 5:08:10 hours and 4:33:35 hours of casting no. 2. Even the various arrangements of chills did not significantly influence the difference in the total solidification time.

\section{CONCLUSION}

The numerical models of the temperature field of the solidifying castings of different authors have observed two main goals: directed solidification as the basic condition for the healthiness of a casting and the optimization of the technology of pouring, while, optimizing the utility properties of the product. Achieving these goals is conditioned by the ability to analyze and to successively control the influence of the deciding factors that either characterize the solidification process or accompany it. It is advantageous to focus the analysis a)
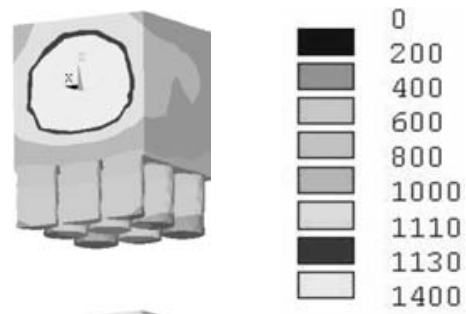

b)

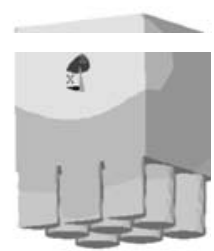

Figure 10: The calculated iso-zones in casting no. 1 and in its chills a) $\tau=1 \mathrm{~h}, \mathrm{~b}) \tau=5 \mathrm{~h}$

Slika 10: Izračunane izotemperaturne cone $\mathrm{v}$ ulitku št. $1 \mathrm{~s}$ hladili a) $\tau$ $=1 \mathrm{~h}, \mathrm{~b}) \tau=5 \mathrm{~h}$

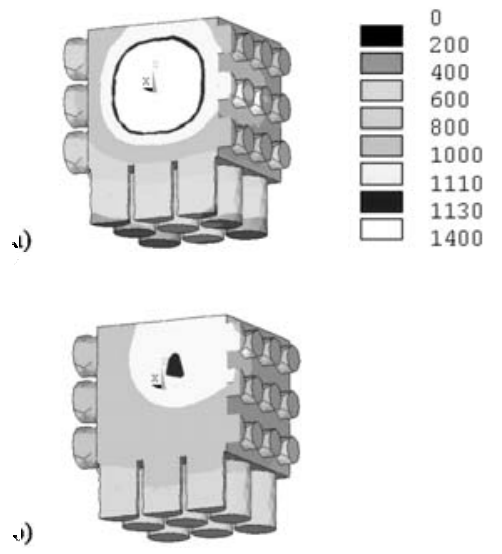

Figure 11: The calculated iso-zones in casting no. 2 and in its chills a) $\tau=1 \mathrm{~h}, \mathrm{~b}) \tau=4,5 \mathrm{~h}$

Slika 11: Izračunane izo-temperaturne cone v ulitku št. 2 s hladili a) $\tau$ $=1 \mathrm{~h}, \mathrm{~b}) \tau=4,5 \mathrm{~h}$

especially on a breakdown of the causes behind the formation of the non-homogeneities within the casting, considering the latent and structural changes, on the thermokinetic formation of the contractions and cavities, on the prediction of their forming, thus, managing to optimize the shape and size of the risers, the method of insulation, the treatment of the level, etc. The main economic goal observed is the saving of liquid material, molding and insulation materials, the saving of energy and the already mentioned optimization of pouring and the properties of the cast product.

This paper has been discussing an original application of ANSYS for the investigation into a temperature field of a massive casting of ductile cast-iron with spheroidal graphite, which makes it possible to evaluate the local solidification times and the local rates of solidification and cooling. Using these parameters, together with the model of microstructural and chemical heterogeneity, it is possible to design the technology of pouring a casting of massive cast-iron with spheroidal graphite (i.e. for example a system of chills) in such a way so as to optimize the quality of the casting even from the viewpoint of its pouring structure.

Acknowledgments. This analysis was conducted using a program devised within the framework of the GA CR projects No. 106/06/1210, 106/06/1225, $106 / 06 / 0393$, 106/08/0606 and 106/08/1243, 106/09/0940.

\section{NOMENCLATURE}

\begin{tabular}{|c|l|l|}
\hline$c$ & specific heat capacity & $\mathrm{J} \mathrm{kg}^{-1} \mathrm{~K}^{-1}$ \\
$h_{\mathrm{v}}$ & specific volume enthalpy $h_{\mathrm{v}}=h \rho$ & $\mathrm{J} \mathrm{m}^{-3}$ \\
$k$ & heat conductivity & $\mathrm{W} \mathrm{m} \mathrm{K}^{-1}$ \\
$\boldsymbol{\tau}$ & time & $\mathrm{s}$ \\
$x, y, z$ & axes in given directions & \\
$T$ & temperature & $\mathrm{K}$ \\
$\rho$ & density & $\mathrm{kg} \mathrm{m}^{-3}$ \\
\hline
\end{tabular}




\section{F. KAVICKA ET AL.: NUMERICAL OPTIMIZATION OF THE METHOD OF COOLING ...}

\section{REFERENCES}

${ }^{1}$ Popela P., Stochastic programming models and methods for technical applications. Folia Fac. Sci.Nat. Univ. Masarykianae Brunensis, Mathematica, 11 (2002), 181-206

${ }^{2}$ Svantner M., Honner M., The model of cooling of a casting, Research report of the Research Centre of New Technologies, West Bohemian University in Plzen, 2001

${ }^{3}$ Kovarik J., Vavroch O., Determining thermophysical properties of mould mixtures, Research report VZVÚ 07687 Skoda Research Ltd., Plzen 1993
${ }^{4}$ Kavička F., Stetina J.: A numerical model of heat transfer in a system a plate casting-mold-suroundings for optimization. Proceedings of the Conference of the ASME, Seattle, USA, July 2000, $161-168$

${ }^{5}$ Kavicka F., Stetina J.. Anumerical model of heat transfer in a system plate-mold-surroundings. Proceedings of the $6^{\text {th }}$ International Conference on Advanced Computational Methods in Heat Transfer, Spain, Madrid, June 2000, 95-104

${ }^{6}$ Kavicka F. et al.: Optimisation of properties and foundry technology of heavy weight ductile cast-iron castings. Final report of GACR project No.106/01/1164, Brno, 2003 